\title{
Fertility of Leached Chernozem and Productivity of Winter Wheat Depending on Fertilizers in a Forest-steppe Zone
}

\author{
T.K. Lazarov¹, S.Kh. Dzanagov¹, A.V. Gazdanov' ${ }^{1}$ A.E. Basiev¹, Z.T. Kanukov", \\ R.A. Tsutsiev¹, A.Yu. Khadikov', and B.S. Kaloev² \\ ${ }^{1}$ Department of Agrochemistry and Soil Science, Gorsky State Agricultural University, \\ Vladikavkaz, Russia \\ ${ }^{2}$ Department of Feeding, Cultivation and Genetics of Farm Animals, Gorsky State Agricultural \\ University, Vladikavkaz, Russia
}

\section{Abstract}

The study revealed optimum doses, NPK combinations, terms and methods of fertilizer application, which provides for highly efficient use of nutrients thus maintaining the fertility of soils, high efficiency and high quality of winter wheat grains. The application of some mineral fertilizers was followed by some decrease (trend) of humus content in relation to control samples. The option manure+NPK was characterized by relative

Corresponding Author:

T.K. Lazarov

t-101271@yandex.ru

Received: 25 October 2019

Accepted: 15 November 2019

Published: 25 November 2019

Publishing services provided by Knowledge E

(c) T.K. Lazarov et al. This article is distributed under the terms of the Creative Commons

Attribution License, which permits unrestricted use and redistribution provided that the original author and source are credited.

Selection and Peer-review under the responsibility of the AgroSMART 2019 Conference Committee.

\section{G OPEN ACCESS} stabilization of humus condition of soil, and concerning the average humus content this option exceeded the control one by $0.32 \%$. Fertilizers clearly improved the nutrient status of leached chernozem under winter wheat enriching its $0--40 \mathrm{~cm}$ layer with mobile nitrogen $\left(\mathrm{NH}_{4}{ }^{+}\right.$and $\left.\mathrm{NO}_{3}{ }^{-}\right)$, phosphorus and potassium respectively by 6.0--9.2; 3.2--9.4; 9.3--36.7 and 21.5--32.8 mg/kg of soil on average per vegetation. Options with high doses of mineral fertilizers were characterized by the largest content. The application of fertilizers under winter wheat in $\mathrm{N}_{50-150} \mathrm{P}_{40-120} \mathrm{~K}_{40-120}$ doses increased grain yield from 0.22 to 2.32 t/ha (6.9--72.5 \%). The estimated option was the best.

\section{Introduction}

In agricultural production the fertility of soil is critical. Its preservation and increase is the main method of improving the efficiency of soil [1].

By estimating the level of crop productivity in dynamics per crop rotation it is difficult to establish the accurate dependence on fertilizers. Therefore, there is a need to study the influence of long-term application of fertilizers on the nutrient status of soil to ensure the formation of crops and the quality of grains [2].

Winter wheat is one of the most important, most valuable and high-yield grain crops in world agriculture. The main crop acreages are placed across Russia in favorable wintering conditions. This culture is more yielding than winter rye and spring wheat provided the level of agrotechnology is high and wintering of plants is safe. 


\section{Problem Statement}

1. To study the influence of long-term application of fertilizers on agrochemical properties and nutrient status of leached chernozem. 2 . To establish the influence of fertilizers on productivity of winter wheat grains.

\section{Research Questions}

The study made it possible to reveal the optimal option for the fertilizer system of winter wheat ensuring high efficiency with improved quality indicators of grain thus maintaining soil fertility and increasing economic efficiency of fertilizers. The obtained data on nutrient removal with harvests and optimum concentration of nutrients in plants during different growth phases and estimated balance coefficients allow performing vegetable diagnostics and calculating optimum doses of fertilizers for planned harvest in these specific conditions more precisely. The received results can also be used in education to study agricultural chemistry and soil science.

\section{Purpose of the Study}

To reveal the optimal option for the fertilizer system of winter wheat in field crop rotation for a forest-steppe zone on leached chernozem, which is characterized by high increase yield gain, soil conservation and enrichment, lack of negative influence on the environment.

\section{Research Methods}

The study was conducted on lands of the Gorsky State Agricultural University in a foreststeppe zone on leached chernozem within long stationary field experiment conducted by the Department of Agricultural Chemistry and Soil Science launched in 1971 in a 5pole field crop rotation (perennial grasses; winter wheat; corn; potatoes; winter wheat) to study the influence of systematic use of fertilizers within crop rotation on its efficiency. In the experiment the crop rotation is carried out in time since it is a model crop rotation.

In 2018 winter wheat of the Yuna grade was studied.

In the experiment different doses and combinations of NPK, three NPK levels, comparative effect of mineral and organic fertilizers were studied.

Experimental design: 
1. Control (without fertilizers)

2. $\mathrm{N}_{1} \mathrm{P}_{1} \mathrm{~K}_{1}$

3. $\mathrm{N}_{2} \mathrm{P}_{1} \mathrm{~K}_{1}$

4. $\mathrm{N}_{1} \mathrm{P}_{2} \mathrm{~K}_{1}$

5. $\mathrm{N}_{2} \mathrm{P}_{2} \mathrm{~K}_{1}$

6. $\mathrm{N}_{2} \mathrm{P}_{2} \mathrm{~K}_{2}$

7. $\mathrm{N}_{3} \mathrm{P}_{2} \mathrm{~K}_{1}$

8. $\mathrm{N}_{3} \mathrm{P}_{2} \mathrm{~K}_{2}$

9. $\mathrm{N}_{2} \mathrm{P}_{3} \mathrm{~K}_{1}$

10. $\mathrm{N}_{2} \mathrm{P}_{3} \mathrm{~K}_{2}$

11. $\mathrm{N}_{3} \mathrm{P}_{3} \mathrm{~K}_{1}$

12. $\mathrm{N}_{3} \mathrm{P}_{3} \mathrm{~K}_{3}$

13. Manure + NPK

14. Estimated.

One NPK dose corresponds to the dose recommended by the results of short-term experiments and makes $\mathrm{N}_{50} \mathrm{P}_{30} \mathrm{~K}_{30}$. Options manure+NPK and $\mathrm{N}_{2} \mathrm{P}_{2} \mathrm{~K}_{2}$ are equivalent according to their NPK level. In estimated option the dose of $\mathrm{N}_{110} \mathrm{P}_{95} \mathrm{~K}_{75}$ fertilizers calculated via a balance method for planned grain yield made $5.5 \mathrm{t} / \mathrm{ha}$.

Fertilizers were applied via split application method. In autumn ammonia nitrate, double superphosphate and potash salt were introduced under preplant cultivation. Simple granular superphosphate was applied during planting in the dose of $10 \mathrm{~kg}$ of the rate of application/hectare. Nitrogen fertilization with ammonium nitrate $\mathrm{N}_{30}$ was carried out in early spring. On options with a threefold dose of nitrogen the second nitrogen fertilization (foliage spraying) with $\mathrm{N}_{30}$ urea solution was carried out.

The plot area makes $100 \mathrm{~m}^{2}$. Quadruplicated frequency.

To study agrochemical properties and the nutrient status of soil the soil samples were taken from contrast options (control, $\mathrm{N}_{1} \mathrm{P}_{1} \mathrm{~K}_{1}, \mathrm{~N}_{2} \mathrm{P}_{2} \mathrm{~K}_{2}, \mathrm{~N}_{3} \mathrm{P}_{3} \mathrm{~K}_{3}$, manure+NPK, estimated), from two non-adjacent replications, from 2 layers: $0--20$ and $20--40 \mathrm{~cm}$, according to plant vegetative stages.

The following was defined in samples: 
- humus content -- according to Tyurin;

- content of absorbed ammonium -- according to Konev;

- content of nitrates -- according to Grandval Lyazhu;

- content of labile phosphorus and exchangeable potassium -- according to Chirikov.

The harvest was taken in manually thus considering the measuring method (trial sheaf) with subsequent weighing.

Mathematical processing of yield data was made via analysis-of-variance method (B.A. Dospekhov).

\section{Results and Discussion}

Humus is the key indicator of soil fertility. Its contents and stocks affect agronomical valuable properties of soil. It is the nutrient source for plants, first of all with nitrogen, considerably increases absorption capacity of soil, improves structure and air and water regime, physical and mechanical properties [1, 3--5].

On long agricultural use without fertilizers the fertility of leached chernozem demonstrates a clear tendency towards reduction though it is early to consider it catastrophic. On the use of mineral and organic fertilizers the negative trend is smoothed, especially concerning humus, which content is not only decreased, but, on the contrary, increased [6].

The study showed that during vegetation of winter wheat the humus content in arable and subsurface soil layers on nil treatment option was weakly changed (Fig. 1).

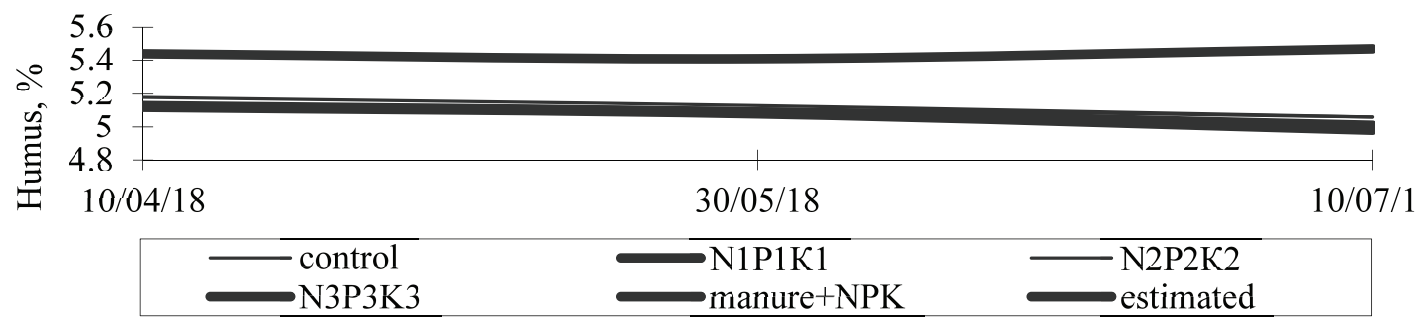

Figure 1: Humus content in a 0--40 cm layer of leached chernozem layer under winter wheat depending on fertilizers, \%.

The introduction of some mineral fertilizers was followed by some decrease (trend) of humus content in relation to the control option. This confirms the opinion of some 
scientists that fertilizers ensure bigger humus mineralization due to the influence of acid fertilizers and activation of microflora upon fertilization.

The option manure+NPK showed relative stabilization of humus condition of soil, and on average humus content per vegetation this option surpassed the control one by 0.32 $\%$. This is quite natural since the organic substance exposed to soil humification gets to soil with manure.

Thus, the organo-mineral fertilization system ensured more favorable change of humus content in soil.

Only mineral forms of nitrogen, i.e. ammonium and nitrate, which are formed in soil through ammonification and nitrification are available to plants. They are easily mobile in soil, especially nitrate, and can be washed out from arable to underlying layers.

The study showed that fertilizers have a positive influence on ammonium content in soil (Fig. 2).

For the option without fertilizers at the beginning of vegetation it was minimum. With activation of ammonifying bacteria it increased prior to active consumption of nitrogen by plants then again decreased.

Similar situation was also typical for fertilized options, however the maximum ammonium content in soil was at the beginning of spring vegetation of winter wheat, which is explained by the introduction of nitrogen fertilizer.

With the content of absorbed ammonium of $30.2 \mathrm{mg} / \mathrm{kg}$ of soil in the control option on average per vegetation, in fertilized options this indicator was significantly higher: for single NPK dose -- by $6.0 \mathrm{mg} / \mathrm{kg}$ (19.9\%), double -- by $7.4 \mathrm{mg} / \mathrm{kg}$ (24.5\%), threefold -- by $9.0 \mathrm{mg} / \mathrm{kg}$ (30.0\%), and the largest content of absorbed ammonium in soil was in the estimated option -- $39.4 \mathrm{mg} / \mathrm{kg}$, which exceeded the control option by $9.2 \mathrm{mg} / \mathrm{kg}$ or $30.4 \%$.

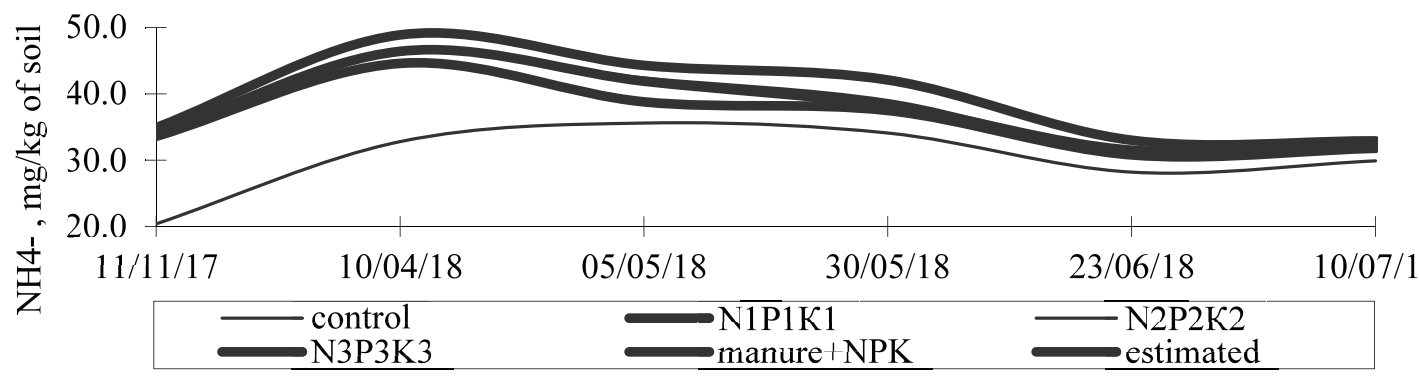

Figure 2: Dynamics of absorbed ammonium in a 0--40 cm layer of leached chernozem under winter wheat depending on fertilizers, $\mathrm{mg} / \mathrm{kg}$. 
Joint introduction of manure and mineral fertilizers had no advantage compared to the introduction of purely mineral fertilizers -- the content of absorbed ammonium in both options was almost similar.

In the arable layer under winter wheat there was more ammonium than in subsurface layer, which is explained by its smaller mobility connected with absorption by SAC colloids (soil adsorption complex).

Along with ammonia nitrogen nitrate nitrogen plays a key role in plant nutrition. Nitrates are better accumulated by plants than ammonium during the initial stage of their development and on sour soils. According to many scientists, the content of nitrates in soil characterizes its fertility.

Nitrates are not absorbed by soil, but can be found in soil solution and thus can be easily washed out deep down. Due to such increased mobility of nitrates their content in soil can considerably vary, which is justified by our study. In our observations the content of nitrates in soil was typically lower than ammonium (Fig. 3).

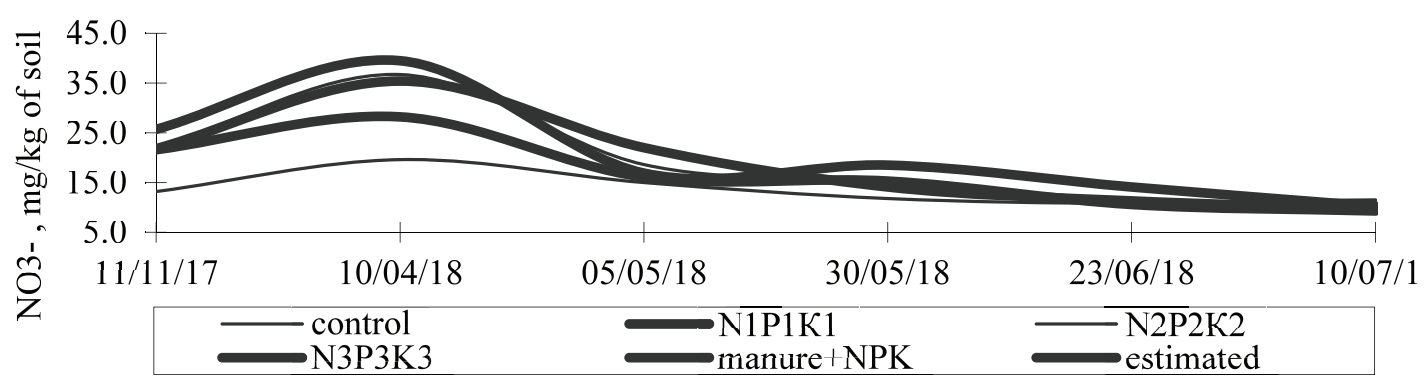

Figure 3: Dynamics of nitrates in a 0--40 cm layer of leached chernozem under winter wheat depending on fertilizers, $\mathrm{mg} / \mathrm{kg}$.

In soil on unfertilized control option from the middle of April to the middle of May there was some increase in nitrate content caused by activation of nitrifying bacteria as a result of soil warmup. The maximum accumulation of nitrates in soil was observed a bit earlier -- in the middle of April. During this period the greatest difference in nitrate content was observed between the options. Then it was decreased though the activity of nitrifying bacteria increased, but there was active consumption of nitrates by plants during their growth and development. Undoubtedly nitrates were washed out during this period with rainfall and as a result of denitrification. By the second decade of June (milky stage) the content of nitrates reached its minimum and almost did not change by the end of vegetation.

The fertilized options considerably surpassed the control ones in terms of nitrate content in soil. If the control option on average per vegetation had $13.6 \mathrm{mg} / \mathrm{kg}$ of soil, 
then with the introduction of a single NPK dose this indicator increased by $3.2 \mathrm{mg} / \mathrm{kg}$ (23.7\%), double -- by $5.6 \mathrm{mg} / \mathrm{kg}$ (41.0\%), threefold -- by $9.4 \mathrm{mg} / \mathrm{kg}(69.0 \%)$-- this option was characterized by the largest content of nitrates in soil. The estimated option took the second place having significantly exceeding the control option -- by $7.2 \mathrm{mg} / \mathrm{kg}$ (52.9 $\%)$.

In terms of nitrate content in soil with joint introduction of organic and mineral fertilizers no difference was found in comparison with the introduction of purely mineral fertilizers.

The difference between the content of nitrates in arable and subsurface layers was irregular. In some cases there were more nitrates in arable, in others -- in subsurface layer. This is caused by increased mobility of nitrates and their continuous migration along a profile, as well as by plant uptake.

Thus, the use of fertilizers leads to clear improvement of the nitrogen status of leached chernozem thus enriching it with mobile forms of nitrogen, thereby increasing effective fertility of soil.

Along with nitrogen, phosphorus plays an extremely important role in the plant life. Phosphatic mode of soil was changed during the vegetation of winter wheat: mobilization of phosphorus in fertilized options was much more intense than in control options and the amount of labile phosphorus significantly exceeded the option without fertilizers. The content of labile phosphorus in soil gradually increased and reached its maximum by the beginning of May and then was decreased before harvesting (Fig. 4).

The content of labile phosphorus in unfertilized control option on average per vegetation made $79.2 \mathrm{mg} / \mathrm{kg}$ of soil. In fertilized option it was significantly higher: in single NPK dose -- by $9.3 \mathrm{mg} / \mathrm{kg}$ (11.8 \%), double -- by $22.2 \mathrm{mg} / \mathrm{kg}$ (28.0\%), threefold -- by 36.7 (46.3\%) -- this was the maximum value. The estimated option, which exceeded the control one by $35.2 \mathrm{mg} / \mathrm{kg}$ or $44.4 \%$ took the second place.

In terms of the content of labile phosphorus in soil the organo-mineral system had insignificant advantage $(2.5 \mathrm{mg} / \mathrm{kg})$ compared to the mineral system.

The arable layer, in which fertilizers were introduced, was more enriched with labile phosphorus, while the subsurface layer was enriched less. This is also caused by the activity of plants absorbing phosphoric acid compounds from deep soil layers and partially leaving phosphates at dying in the top layer where the majority of roots is concentrated.

The obtained data confirm the positive influence of fertilizers on phosphatic status of leached chernozem. The introduced fertilizers significantly enriched the soil with labile 


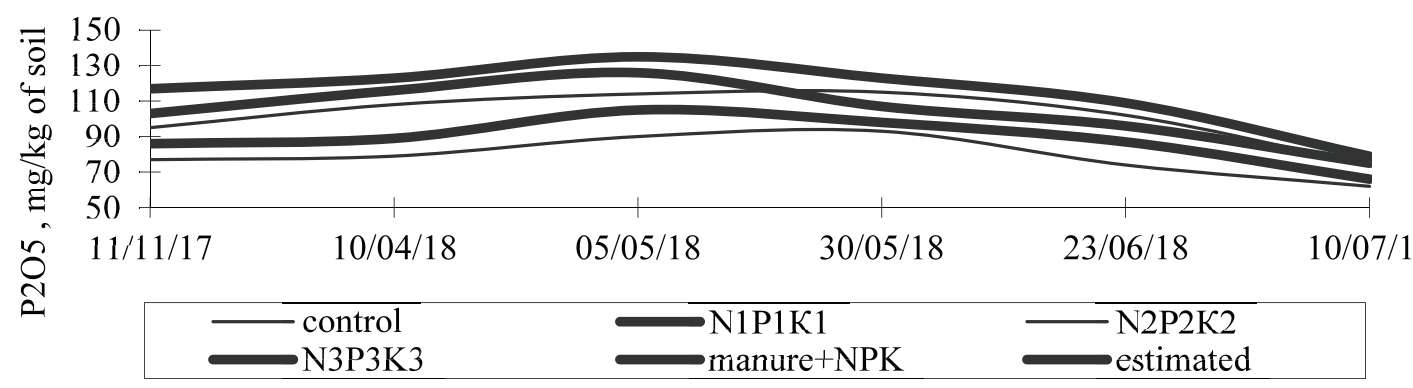

Figure 4: Dynamics of labile phosphorus in a $0--40 \mathrm{~cm}$ layer of leached chernozem under winter wheat depending on fertilizers, $\mathrm{mg} / \mathrm{kg}$.

phosphorus. According to many scientists, the use of physiologically sour nitrogen and potash fertilizers significantly mobilizes soil phosphorus.

Potassium, unlike nitrogen, has no visible impact on the efficiency of cultivated plants, but it defines all qualitative, including technological, indicators of crop products. Plants are able to acquire water-soluble and exchangeable potassium from soil.

In our study the content of exchangeable potassium in soil under winter wheat changed less sharply than phosphorus. In unfertilized control option since the beginning of vegetation until the end of May (earing-blossoming) it gradually increased, then sharply decreased to the end of vegetation (Fig. 5).

Fertilizers had a positive influence on the potash status of leached chernozem, they enriched the arable layer with potassium and provided better exchangeable potassium to plants. The content of exchangeable potassium in soil of unfertilized option made $131.7 \mathrm{mg} / \mathrm{kg}$. In soil of fertilized options this indicator was $21.5 \mathrm{mg} / \mathrm{kg}$ higher (16.3 \%) in a single NPK dose, $28.2 \mathrm{mg} / \mathrm{kg}$ (21.4 \%) -- in double, $32.8 \mathrm{mg} / \mathrm{kg}$ (24.9 \%) -- in threefold, and the largest content was recorded in the estimated option -- $29.8 \mathrm{mg} / \mathrm{kg}(22.7 \%)$. The organo-mineral system had insignificant advantage $(0.8 \mathrm{mg} / \mathrm{kg})$ compared to mineral.

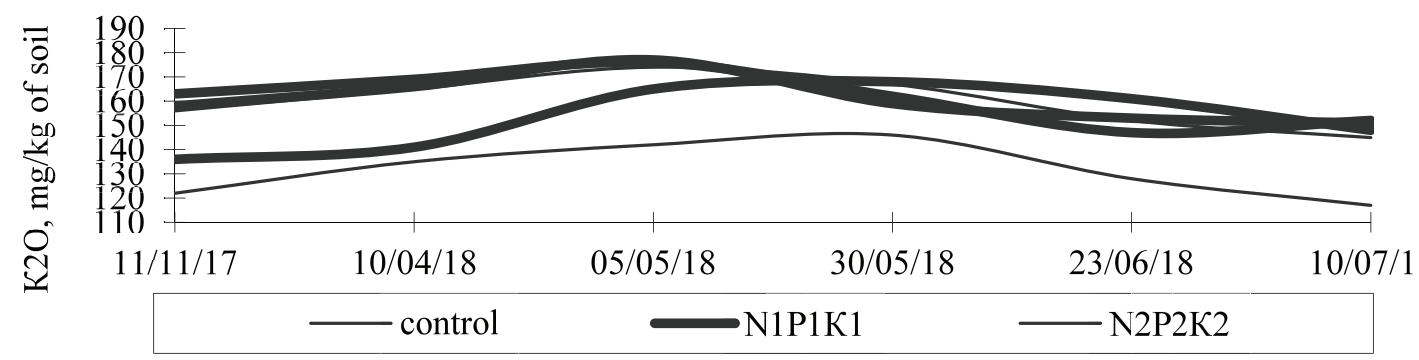

Figure 5: Dynamics of exchangeable potassium in a 0-40 cm layer of leached chernozem under winter wheat depending on fertilizers, $\mathrm{mg} / \mathrm{kg}$.

According to some scientists, at frequent change of moistening and drying of soil the potassium introduced with fertilizers, especially in chernozems can shift into nonexchangeable state thus reducing its availability to plants. 
With depth the content of potassium decreased, which is caused by bigger activity of biological processes and application of fertilizers in the arable layer.

Thus, the introduced fertilizers clearly improved the nutrient status of leached chernozem under winter wheat thus enriching its $0--40 \mathrm{~cm}$ layer with mobile forms of nitrogen $\left(\mathrm{NH}_{4}{ }^{+}\right.$and $\left.\mathrm{NO}_{3}{ }^{-}\right)$, phosphorus and potassium respectively by 6.0--9.2; 3.2-9.4; 9.3--36.7 and $21.5--32.8 \mathrm{mg} / \mathrm{kg}$ of soil on average per vegetation. The options with high doses of mineral fertilizers were characterized by the largest content.

Long-term experiments confirm the increase of winter wheat productivity with the introduction of different fertilizer systems [7--9]. However, these studies were mainly performed within short-term experiments without considering grade, predecessor and edaphoclimatic factors. Other regularities can be observed at prolonged use of fertilizers in crop rotation [10].

In our study the introduction of mineral fertilizers under winter wheat considerably increased its productivity in all options (Tabl. 1).

Despite adverse weather conditions, the option without fertilizers demonstrated quite high productivity of grain -- $3.20 \mathrm{t} / \mathrm{ha}$. All fertilized options are characterized by considerable yield gain: in a single NPK dose the productivity increased by $0.22 \mathrm{t} / \mathrm{ha}$ or $6.9 \%$, double -- by 1.74 t/ha or $54.4 \%$, threefold -- by 1.50 t/ha or $46.9 \%$.

Doubling of the nitrogen dose against the background of $\mathrm{P}_{1} \mathrm{~K}_{1}$ provided additional $0.32 \mathrm{t} / \mathrm{ha}(9.4 \%)$ of the yield gain. More considerable yield gain -- $0.56 \mathrm{t} / \mathrm{ha}$ (16.0\%) was from doubling of the phosphorus dose against the background of $N_{1} K_{1}$. But at simultaneous doubling of nitrogen and phosphorus doses it became more critical -$0.90 \mathrm{t} / \mathrm{ha}$ (26.3\%). The doubling of the potassium dose against the background of $\mathrm{N}_{2} \mathrm{P}_{2}$ increased yield gain by $0.62 \mathrm{t} /$ ha $(14.4 \%)$ though, according to many researchers, potash fertilizers poorly affect the yield gain of winter wheat.

With the increase of the NPK dose to the double level the yield gain made $4.94 \mathrm{t} / \mathrm{ha}$, i.e. more than 1.5 times ( $54.4 \%$ ) than in control option and by $1.52 \mathrm{t} / \mathrm{ha}$ ( $44.4 \%$ ) higher than in the option with a single dose.

The biggest grain yield of winter wheat is received in the estimated option -- 5.52 t/ha (yield gain -- $72.5 \%$ ), options with a double dose of fertilizers take the second place, and the organo-mineral system provided bigger grain yield -- $2.22 \mathrm{t} /$ ha (yield gain -$69.4 \%$ ) than the mineral $-1.74 \mathrm{t} /$ ha (yield gain -- $54.4 \%$ ). The productivity was lower in the option with a threefold dose of fertilizers.

The use of fertilizers under winter wheat also increased the yield of by-products. The dependence of a straw yield on the level of mineral nutrition was a bit different. The 
TABLE 1: Productivity of winter wheat grain depending on fertilizers (2018).

\begin{tabular}{|l|l|l|l}
\hline Option & Productivity, $\mathrm{t} / \mathrm{ha}$ & & \multicolumn{2}{c}{ Gain } \\
\hline Control & & t/ha & \\
\hline $\mathrm{N}_{1} \mathrm{P}_{1} \mathrm{~K}_{1}$ & 3.20 & & 6.9 \\
\hline $\mathrm{N}_{2} \mathrm{P}_{1} \mathrm{~K}_{1}$ & 3.42 & 0.22 & 16.9 \\
\hline $\mathrm{N}_{1} \mathrm{P}_{2} \mathrm{~K}_{1}$ & 3.74 & 0.54 & 24.4 \\
\hline $\mathrm{N}_{2} \mathrm{P}_{2} \mathrm{~K}_{1}$ & 3.98 & 0.78 & 35.0 \\
\hline $\mathrm{N}_{2} \mathrm{P}_{2} \mathrm{~K}_{2}$ & 4.32 & 1.12 & 54.4 \\
\hline $\mathrm{N}_{3} \mathrm{P}_{2} \mathrm{~K}_{1}$ & 4.94 & 1.74 & 38.1 \\
\hline $\mathrm{N}_{3} \mathrm{P}_{2} \mathrm{~K}_{2}$ & 4.42 & 1.22 & 40.9 \\
\hline $\mathrm{N}_{2} \mathrm{P}_{3} \mathrm{~K}_{1}$ & 4.51 & 1.31 & 40.3 \\
\hline $\mathrm{N}_{2} \mathrm{P}_{3} \mathrm{~K}_{2}$ & 4.49 & 1.29 & 44.4 \\
\hline $\mathrm{N}_{3} \mathrm{P}_{3} \mathrm{~K}_{1}$ & 4.62 & 1.42 & 40.9 \\
\hline $\mathrm{N}_{3} \mathrm{P}_{3} \mathrm{~K}_{3}$ & 4.51 & 1.31 & 46.9 \\
\hline $\mathrm{Manure}_{2} \mathrm{NPK}$ & 4.70 & 1.50 & 69.4 \\
\hline $\mathrm{Estimated}_{2}$ & 5.42 & 2.22 & 72.5 \\
\hline $\mathrm{HCP}_{0.5}$ & 5.52 & 2.32 & \\
\hline & 0.16 & & \\
\hline
\end{tabular}

option $\mathrm{N}_{3} \mathrm{P}_{3} \mathrm{~K}_{3}$ was the best in a straw harvest of $5.15 \mathrm{t} / \mathrm{ha}$ within the control option and made $4.42 \mathrm{t} / \mathrm{ha}$ or $85.9 \%$. The estimated option took the second place -- $9.32 \mathrm{t} / \mathrm{ha}$ (81.1 \%).

Thus, the use of fertilizers under winter wheat in doses of $\mathrm{N}_{50-150} \mathrm{P}_{30-95} \mathrm{~K}_{30-90}$ ensured the yield gain of grain from 0.22 to $2.32 \mathrm{t} / \mathrm{ha}(6.9--72.5 \%)$ and straw -- from 0.55 to 4.42 t/ha (10.6--85.9 \%). The estimated option was the best.

\section{Conclusion}

1. The introduction of some mineral fertilizers was followed by some decrease (trend) of humus content in relation to the control option. The option manure+NPK showed relative stabilization of humus condition of soil, and on average humus content per vegetation this option surpassed the control one by $0.32 \%$.

2. The introduced fertilizers clearly improved the nutrient status of leached chernozem under winter wheat thus enriching its $0--40 \mathrm{~cm}$ layer with mobile forms of nitrogen $\left(\mathrm{NH}_{4}{ }^{+}\right.$ and $\mathrm{NO}_{3}{ }^{-}$), phosphorus and potassium respectively by 6.0--9.2; 3.2--9.4; 9.3--36.7 and 
21.5--32.8 $\mathrm{mg} / \mathrm{kg}$ of soil on average per vegetation. The options with high doses of mineral fertilizers were characterized by the largest content.

3. The use of fertilizers under winter wheat in doses of $\mathrm{N}_{50-150} \mathrm{P}_{40-120} \mathrm{~K}_{40-120}$ ensured the yield gain of grain from 0.22 to $2.32 \mathrm{t} /$ ha $(6.9--72.5 \%)$. The estimated option was the best.

\section{References}

[1] Dzanagov, S.Kh., Lazarov, T.K., Basiev, A.E., Kanukov, Z.T., Khadikov, A.Y. (2014). Influence of Sustained Fertilization on the Amount of Humus and Effective Fertility of Leached Chernozem. American-Eurasian Journal of Sustainable Agriculture, no. 8(9), pp. 35--40.

[2] Gospodarenko, G.N., Lubich, V.V., Matvienko, N.P. (2018). Quality of wheat winter grains after long (since 1965) use of fertilizers in field crop rotation. Relevant scientific study in modern world, no. 1--5(33), pp. 134--138.

[3] Sheudzhen, A.Kh. (2015). Chernozem Agrochemistry. Maykop: JSC Poligraf-Yug, pp. 232.

[4] Sheudzhen, A.Kh., Neshchadim, N.N., Onishchenko, L.M. (2011). Organic matter of soil and its ecological functions. Krasnodar: KubSAU, pp. 202.

[5] Bezuglova, O.S. (2001). Humus condition of soils of the South of Russia. Rostov-onDon: NCRC HS, pp. 221.

[6] Dzanagov, S.Kh., Basiev, A.E., Kanukov, Z.T., Lazarov, T.K. (2015). Dynamics of humus content in leached chernozem under the influence of fertilizers. News of Gorsky State Agricultural University, vol. 52, no. 2, pp. 19--24.

[7] Spiridonov, Yu.I., Sokolov, M.S., Bosak, G.S. (2017). Optimized production technology of winter wheat in Central Nonblack Soil Zone of the Russian Federation. Achievements of science and technology of agrarian and industrial complex, no. 6 , pp. 27--30.

[8] Abashev, V.D., Popov, F.A., Noskov, E.N., Zhuk, S.N. (2017). Influence of mineral fertilizers on the productivity of spring wheat. Scientific and practical journal. Perm Agrarian Bulletin, no. 1(17), pp. 7--11.

[9] Skorobogatova, A.S., Filipenko, N.N., Bedirkhanov, M.A. (2017). Efficiency of winter wheat on leached chernozem in the conditions of Western Ciscaucasia. Polythematic network electronic scientific journal of Kuban State Agricultural University, no. 125, pp. 724--737. 
[10] Dzanagov, S.Kh., Lazarov, T.K., Kaloev, B.S., Kubatieva, Z.A., Kalagova, R.V. (2019). Effect of Long-Term Fertilizers on Growth Indicator, Yield and Quality of Winter Wheat Grain. Agrochemistry, no. 4, pp. 31--38. 